\title{
Metabolic risk in depression and treatment with selective serotonin reuptake inhibitors: are the metabolic syndrome and an increase in cardiovascular risk unavoidable?
}

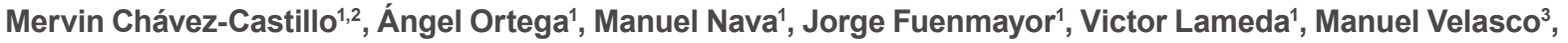 \\ Valmore Bermúdez ${ }^{1,4}$, Joselyn Rojas-Quintero ${ }^{1,5}$ \\ 'Endocrine and Metabolic Diseases Research Center, School of Medicine, The University of Zulia, Maracaibo 4001, Venezuela. \\ ${ }^{2}$ Psychiatric Hospital of Maracaibo, Maracaibo 4001, Venezuela. \\ ${ }^{3}$ Department of Pharmacology, "JM Vargas" Medical School, Central University of Venezuela, Caracas 1050, Venezuela. \\ ${ }^{4}$ Advanced Frontier Studies Research Group (ALEF), Simón Bolívar University, Cúcuta 540006, Colombia. \\ ${ }^{5}$ Division of Pulmonary and Critical Care Medicine, Brigham and Women's Hospital, Harvard Medical School, Boston, MA 02115, USA.
}

Correspondence to: Dr. Mervin Chávez-Castillo, Endocrine and Metabolic Diseases Research Center, School of Medicine, The University of Zulia, Maracaibo 4001, Venezuela. E-mail: mervinch12@gmail.com How to cite this article: Chávez-Castillo M, Ortega Á, Nava M, Fuenmayor J, Lameda V, Velasco M, Bermúdez V, Rojas-Quintero J.
Metabolic risk in depression and treatment with selective serotonin reuptake inhibitors: are the metabolic syndrome and an
increase in cardiovascular risk unavoidable? Vesse/ Plus 2018;2:6. http://dx.doi.org/10.20517/2574-1209.2018.02

Received: 2 Feb 2018 First Decision: 2 Apr 2018 Revised: 3 Apr 2018 Accepted: 9 Apr 2018 Published: 18 Apr 2018

Science Editor: Alexander D. Verin Copy Editor: Jun-Yao Li Production Editor: Cai-Hong Wang

\begin{abstract}
Depression is one of the most common psychiatric disorders, and has become an epidemic in modern medical practice; notorious for frequently co-occurring with multiple comorbidities, especially cardiovascular disease (CVD), type 2 diabetes mellitus (DM2), and its various risk factors comprised in the metabolic syndrome (MS). Selective serotonin reuptake inhibitors (SSRIs) are the most widely used class of psychotropic drugs in this and many other clinical scenarios; yet their impact on cardiometabolic health has not been elucidated. The objective of this review was to summarize current views on the pharmacology of SSRIs and cardiometabolic risk, as well as available epidemiological evidence regarding its clinical significance. SSRIs appear to intervene in cardiometabolic physiology fundamentally by modulating chronic inflammation, a key pathophysiologic phenomenon in MS, DM2 and CVD. However, the dosing necessary to achieve a beneficial impact in this regard, as well as their clinical correlations, remain controversial. Each SSRI displays a particular profile regarding each of the components of the MS: weight gain seems to be the most common effect of SSRIs, more frequent with paroxetine, followed by citalopram and escitalopram. As a drug class, SSRIs also appear to promote hypercholesterolemia rather uniformly, while fluoxetine and citalopram appear to particularly increase triacylglyceride levels. In contrast, fluvoxamine and paroxetine seem to have the greatest impact on dysglycemia. Lastly, most SSRIs appear to be innocuous or even beneficial regarding blood pressure and
\end{abstract}

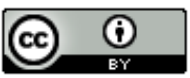

(C) The Author(s) 2018. Open Access This article is licensed under a Creative Commons Attribution 4.0 International License (https://creativecommons.org/licenses/by/4.0/), which permits unrestricted use, sharing, adaptation, distribution and reproduction in any medium or format, for any purpose, even commercially, as long as you give appropriate credit to the original author(s) and the source, provide a link to the Creative Commons license, and indicate if changes were made.

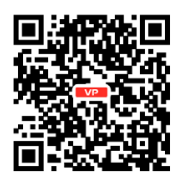


high-density lipoprotein cholesterol. Nevertheless, many of these effects may vary significantly upon specific clinical circumstances, especially timing. This topic remains rather unexplored in clinical psychopharmacology, and further, larger-scale epidemiological studies are needed in order to offer improved care in this field.

Keywords: Depression, selective serotonin reuptake inhibitors, metabolic syndrome, cardiovascular risk, cardiovascular disease, type 2 diabetes mellitus, chronic inflammation

\section{INTRODUCTION}

Depression has become an emerging epidemic in recent years, with prevalence rates of $10 \%-15 \%$ across the globe $^{[1]}$. This trend has resulted in ever-increasing financial costs, along with a significant decay in the life quality of patients ${ }^{[2]}$. A substantial portion of this burden may stem from the multiple medical comorbidities associated with depression, in particular, cardiovascular disease $(\mathrm{CVD})^{[3]}$, with these conditions coexisting in up to $15 \%$ of cases $^{[4]}$.

CVD remains the leading cause of morbidity and mortality worldwide ${ }^{[5]}$, significantly driven by a myriad of modifiable risk factors consequent upon a predominantly Westernized lifestyle ${ }^{[6]}$. The metabolic syndrome (MS), conceptualized as a cluster of cardiovascular risk factors - obesity, hypertension, hyperglycemia and atherogenic dyslipidemia - which in co-occurrence substantially increase the risk of CVD and type 2 diabetes mellitus (DM2), is widely regarded as a useful clinical tool in the prevention of these conditions ${ }^{[7]}$. These factors also appear to be involved in the pathophysiology of depression, and may account for the higher cardiovascular risk observed in this disorder ${ }^{[8,9]}$.

In this context, the pharmacological management of depression presents a clinical conundrum: depression is accompanied by increased risk of MS - and by extension, CVD and DM2 - yet many antidepressant drugs appear to exacerbate these risks as well ${ }^{[10,11]}$. However, in contrast with antipsychotic drugs, whose clinical relevance in regards to deleterious cardiometabolic effects has been well-characterized ${ }^{[12,13]}$, the impact of antidepressant drugs in clinical outcomes remains less clear. This is an especially pressing matter in the field of neuropsychopharmacology, as antidepressant drugs, and selective serotonin reuptake inhibitors (SSRIs) in particular, have become one of the most prescribed drug classes in contemporary medical practice ${ }^{[14,15]}$. This review aims to summarize current views on the pharmacology of SSRIs and cardiometabolic risk, as well as available epidemiological evidence regarding its clinical significance.

\section{SSRI-ASSOCIATED CARDIOMETABOLIC RISK: MOLECULAR PATHWAYS}

SSRIs have become very popular in clinical use owing to various beneficial characteristics, including their ease of administration, increased pharmacodynamic specificity, and enhanced tolerability with relatively minor side effects; in contrast to the "dirtier", less specific and tolerable older antidepressant drugs, such as tricyclics and monoamine oxidase inhibitors ${ }^{[16]}$. Although this distinction is notorious regarding cardiovascular safety, the underlying molecular differences in their pharmacologic profiles remain largely elusive $e^{[17]}$.

Chronic systemic inflammation may be an especially important target for SSRIs in this context, given the comprehensive involvement of this phenomenon in the pathophysiology of MS, CVD and DM2 $2^{[18]}$. Furthermore, this kind of low-grade inflammation is also present in depression, as patients with disorder tend to show increased levels of proinflammatory biomarkers such as tumor necrosis factor alpha (TNF $\alpha$ ), C-reactive protein, interleukin (IL)- 6 and IL-1 $\beta^{[19]}$. This is compounded by the frequent accompaniment of depression with unhealthy dietary habits and physical inactivity, which themselves also promote chronic inflammation ${ }^{[20]}$, and are prominent in the development of depressive symptoms such as loss of energy, sleep disturbances and irritability ${ }^{[2]}$. 
Interestingly, the onset of the antidepressant effect of SSRIs has been reported to coincide with a reduction in the circulating levels of proinflammatory biomarkers ${ }^{[22]}$. A novel hypothesis posits these changes to be due to a T helper (Th1)-like response, triggering inflammatory activity via interferon $\gamma\left(\right.$ IFN $\gamma$ )-related pathways ${ }^{[23]}$. SSRIs appear to decrease the production of INF $\gamma$ and stimulate the release of IL-10, by modulating the corresponding mRNA in immune cells ${ }^{[24]}$. Consistent with this, SSRIs also appear to upregulate the expression of genes involved in apoptotic pathways in $\mathrm{T}_{\text {cells }} \mathrm{s}^{[25]}$. In addition, blockade of serotonin reuptake results in increased circulating serotonin levels, which have been reported to be able to suppress cytokine synthesis by T cells, B cells, natural killer cells and monocytes/macrophages ${ }^{[26-29]}$, resembling what occurs in sepsis after massive platelet degranulation ${ }^{[30]}$.

Macrophages may be particularly relevant regarding the immunomodulatory effects of SSRIs due to their high expression of serotonin receptors ${ }^{[31,32]}$. By acting as ambient serotonin level sensors, macrophages could modulate genotype expression patterns in macrophages: activation of $5 \mathrm{HT}_{7}$ receptors in macrophages has been noted to induce polarization towards the antiinflammatory M2 phenotype ${ }^{[33,34]}$. Inhibition of TNF $\alpha$ and IL-6 release, as well as promotion of IL-10 synthesis, are prominent among the antiinflammatory features of M2 macrophages ${ }^{[33,35,36]}$.

Nevertheless, these antiinflammatory effects have been speculated to occur only at doses greater than the usual therapeutic range ${ }^{[3]]}$, and SSRIs may rather be proinflammatory at lower doses, especially with prolonged use ${ }^{[38]}$. This is consistent with evidence from Kubera et al. ${ }^{[27]}$, who found physiological levels of intracellular serotonin tend to promote TNF $\alpha$ and IL-6 synthesis in macrophages, whereas supraphysiological levels of extracellular serotonin were linked with downregulation of serotonin receptors serotonin receptors and with decreased release of with decreased release of proinflammatory cytokines. Further research is required to elucidate the clinical correlates and significance of this molecular framework for SSRI-mediated immunomodulation.

Chronic inflammation is also closely linked to insulin resistance and obesity, two fundamental elements of the MS. Thus, by intervening through immunomodulation, SSRIs could have a pivotal role in the pathophysiology of this cluster of manifestations ${ }^{[39]}$. Paroxetine may be a particularly powerful inductor of insulin resistance by interfering with IRS-1 signaling ${ }^{[40]}$. Indeed, each SSRI seems to exert distinct effects on insulin resistance, body weight composition, and serum lipids, independently of their impact on chronic inflammation. For example, paroxetine has been linked with higher low-density lipoprotein cholesterol (LDL-C) levels, possibly due to increased appetite ${ }^{[41]}$; whereas fluoxetine, by inhibiting PON1 activity, may favor lower high-density lipoprotein cholesterol (HDL-C) levels ${ }^{[42]}$. In addition, certain pharmacokinetic interactions, such as that of fluoxetine with statins - including inhibition of CYP3A and modulation of glucuronidation, P-glycoprotein (Pgp) and organic anion transport peptide 1B1 (OATP), may result in potentiated reduction of cholesterol ${ }^{[43]}$. This complexity warrants further insight and an individual assessment of each specific SSRI in this context. In stark contrast, SSRIs seem to be relatively innocuous regarding blood pressure, unlike other antidepressant drug classes such as serotonin-norepinephrine reuptake inhibitors, monoamine oxidase inhibitors, and tricyclic antidepressants ${ }^{[44-46]}$.

Lastly, the prominent role of serotonin in platelet physiology has ignited speculation regarding SSRIs as antiplatelet agents ${ }^{[47,48]}$. The higher concentrations of circulating serotonin induced by SSRIs could reduce platelet aggregation ${ }^{[49,50]}$ and impair reactivity to vasoconstriction ${ }^{[51]}$. However, SSRIs do not appear to intervene in the functionality of vitronectin - a fundamental component of glycoprotein $\mathrm{IIb} / \mathrm{III} \mathrm{a}^{[48]}$ - or fibrinogen ${ }^{[52]}$; but are able to regulate the expression of vascular adhesion molecules such as VCAM-1, ICAM1 , P-selectin and E-selectin ${ }^{[53,54]}$. Nevertheless, the relative relevance of these effects remains unknown in the context of the chronic inflammatory milieu which SSRIs could promote simultaneously, as does the clinical significance of this antiplatelet activity. 
Table 1. Comparison of the clinical effects of SSRIs in key metabolic variables

\begin{tabular}{|c|c|c|c|c|c|c|c|c|}
\hline \multirow[t]{2}{*}{ SSRIs } & \multirow[t]{2}{*}{ Body weight } & \multirow[t]{2}{*}{ Glycemia } & \multicolumn{4}{|c|}{ Serum Lipids } & \multirow{2}{*}{$\begin{array}{l}\text { Blood } \\
\text { pressure }\end{array}$} & \multirow[t]{2}{*}{ References } \\
\hline & & & TAG & HDL-C & LDL-C & TC & & \\
\hline Paroxetine & $\begin{array}{l}\text { Short-term: N } \\
\text { Long-term: } \uparrow \uparrow \uparrow\end{array}$ & $\begin{array}{l}\text { Short-term: } \downarrow \\
\text { Long-term: } \uparrow \uparrow \uparrow\end{array}$ & $\uparrow \uparrow$ & $\mathrm{N}$ & $\uparrow$ & $\uparrow \uparrow$ & $\mathrm{N}$ & $\begin{array}{l}{[59,67,68,75,80,81,85,} \\
88-90,94,96,99,101-104]\end{array}$ \\
\hline Fluoxetine & $\begin{array}{l}\text { Short-term: } \downarrow \\
\text { Long-term: } \mathrm{N}\end{array}$ & $\downarrow$ & $\uparrow \uparrow$ & N & $\uparrow$ & $\uparrow$ & $\mathrm{N}$ & $\begin{array}{l}{[58,59,64,65,67-70,78,85,} \\
90-92,94,96,99,105-107]\end{array}$ \\
\hline Fluvoxamine & $\mathrm{N}$ & $\uparrow \uparrow \uparrow$ & SE & SE & SE & $\uparrow$ & SE & {$[58,75,84,108-110]$} \\
\hline Sertraline & $\begin{array}{l}\text { Short-term: } \downarrow \\
\text { Long-term: N }\end{array}$ & $\downarrow$ & $\uparrow$ & $\mathrm{N}$ & $\uparrow$ & $\uparrow$ & $N$ & $\begin{array}{l}{[62,63,67,76,85,89,90,93,} \\
94,96,99,111]\end{array}$ \\
\hline Citalopram & $\begin{array}{l}\text { Short-term: } \uparrow \\
\text { Long-term: } \uparrow\end{array}$ & N & $\uparrow \uparrow$ & N & $\uparrow$ & $\uparrow$ & N & $\begin{array}{l}{[58,68,71,79,84,85,90,92,} \\
94,96,99,112]\end{array}$ \\
\hline Escitalopram & $\begin{array}{l}\text { Short-term: } \uparrow \\
\text { Long-term: } \uparrow\end{array}$ & $\downarrow$ & $\uparrow$ & $\uparrow$ & $\uparrow$ & $\uparrow$ & N & {$[66,71,77,85,96,99,113,114]$} \\
\hline
\end{tabular}

$\uparrow:$ increase; $\uparrow \uparrow:$ high increase; $\uparrow \uparrow \uparrow:$ very high increase; $\downarrow$ : decrease; N: neutral; SE: scarce evidence; TAG: triacylglycerides; HDL-C: highdensity lipoprotein cholesterol; LDL-C: low-density lipoprotein cholesterol; TC: total cholesterol; SSRI: selective serotonin reuptake inhibitor

\section{SSRI-ASSOCIATED CARDIOMETABOLIC RISK: CLINICAL EVIDENCE}

Management of metabolic risk is a frequent clinical challenge when prescribing psychiatric medications ${ }^{[55]}$. However, in contrast to other psychotropic drug classes - which tend to behave more or less uniformly in regards to metabolic risk ${ }^{[56]}$, SSRIs appear to have more heterogeneous patterns ${ }^{[57,58]}$. The following sections summarize key clinical evidence regarding the impact of SSRIs on each of the components of the MS [Tables 1 and 2].

\section{Obesity}

Historically, weight changes have been a hallmark in the side effect profile of most antidepressant classes ${ }^{[59-61]}$. In the case of SSRIs, the specific agent used and the length of therapy may account for the very variable effects these drugs appear to have on body weight ${ }^{[59]}$. For example, in two multicenter, double-blind, randomized, placebo-controlled clinical trials assessing sertraline therapy in 376 pediatric patients with major depressive disorder (MDD) over 10 weeks, Wagner et al..$^{[62]}$ found a mean weight loss of $0.38 \mathrm{~kg}$ in subjects treated with sertraline. Croft et al ${ }^{[63]}$ obtained similar outcomes in an 8-week case-control study, with an average weight loss of $0.79 \mathrm{~kg}$ in patients treated with sertraline. Likewise, use of fluoxetine has been linked to short-term weight loss, as reported by de Jonghe et al. ${ }^{[64]}$ in a randomized, double-blind 6-week study, where patients treated with fluoxetine showed an average loss of $0.84 \mathrm{~kg}$; as well as by Michelson et al ${ }^{[65]}$ in a prospective, placebocontrolled trial, where subjects on fluoxetine showed an average weight loss of $0.35 \mathrm{~kg}$ after 12 weeks. However, escitalopram has been linked with a significant increase in waist circumference in the short term ${ }^{[66]}$.

Nevertheless, the clinical value of these findings may be limited due to the short length of these studies, especially when considering treatment guidelines for MDD suggest use of antidepressants for at least 6 months. Therefore, in recent years, more studies have attempted to evaluate the long-term effect of SSRIs on weight ${ }^{[67-7]}$. In a similar 32-week study by Fava et al..$^{[67]}$ with fluoxetine, sertraline and paroxetine, weight gain was significantly higher with the latter. Mansoor et al. ${ }^{[68]}$ found a similar outcome, where citalopram and paroxetine were associated with longterm weight gain, whereas fluoxetine and venlafaxine were not. Fluoxetine in particular is consistently reported not to be linked with any major long-term weight changes ${ }^{[6,70]}$. In contrast, Calarge et al ${ }^{[7]]}$ found citalopram and escitalopram are associated with significant changes in all body composition parameters, including visceral fat mass, after 2 years in treatment for MDD and generalized anxiety disorder.

Notwithstanding this outline, some research has suggested patients with MDD are intrinsically more susceptible to changes in body weight, and these shifts may occur independently of antidepressant use ${ }^{[72]}$. At any rate, at present, there is sufficient evidence to highlight long-term weight gain as a clinically relevant effect for certain SSRIs, underlining the importance of patient-centric prescribing in psychopharmacology. 
Table 2. Summary of key clinical evidence regarding SSRIs and the components of the metabolic syndrome

\begin{tabular}{|c|c|c|c|}
\hline Authors & SSRIs studied & Methodology & Relevant results \\
\hline $\begin{array}{l}\text { Andersohn } \\
\text { et al. }{ }^{[75]}\end{array}$ & $\begin{array}{l}\text { Paroxetine, } \\
\text { sertraline, } \\
\text { fluoxetine, } \\
\text { fluvoxamine } \\
\text { and citalopram }\end{array}$ & $\begin{array}{l}\text { Case-control study with data from the } \\
\text { UK General Practice Research Database, } \\
\text { including } 165,968 \text { patients with depression } \\
\text { who received at least one prescription for } \\
\text { antidepressants between January } 1990 \text { and } \\
\text { June } 2005\end{array}$ & $\begin{array}{l}\text { Fluvoxamine and paroxetine were associated with increased } \\
\text { risk of type } 2 \text { diabetes mellitus: OR } 9.0 \text { ( } 95 \% \mathrm{Cl} 1.08-75.58) \\
\text { and OR } 1.75 \text { ( } 95 \% \mathrm{Cl} 1.13-2.72) \text {, respectively }\end{array}$ \\
\hline $\begin{array}{l}\text { Raeder } \\
\text { et al. }{ }^{[58]}\end{array}$ & $\begin{array}{l}\text { Paroxetine, } \\
\text { sertraline, } \\
\text { fluoxetine, } \\
\text { fluvoxamine } \\
\text { and citalopram }\end{array}$ & $\begin{array}{l}\text { Cross-sectional study with data from the } \\
\text { Hordaland Health Study, including } 25,315 \\
\text { subjects with ages between } 40-49 \text { years } \\
\text { and } 70-74 \text { years }\end{array}$ & $\begin{array}{l}\text { As a group, SSRIs were significantly associated with type } \\
2 \text { diabetes mellitus, hypercholesterolemia and abdominal } \\
\text { obesity. Paroxetine showed the strongest association with } \\
\text { general and abdominal obesity. Conversely, citalopram was } \\
\text { not linked with any of the aforementioned metabolic variables }\end{array}$ \\
\hline $\begin{array}{l}\text { Wagner } \\
\text { et al. }{ }^{[62]}\end{array}$ & Sertraline & $\begin{array}{l}\text { Two multicenter, double-blind, randomized, } \\
\text { placebo-controlled clinical trials which } \\
\text { assessed the safety and efficacy of } \\
\text { sertraline during } 10 \text { weeks in } 376 \text { pediatric } \\
\text { patients diagnosed with MDD }\end{array}$ & $\begin{array}{l}\text { Use of sertraline was associated with a mean weight loss of } \\
0.38 \mathrm{~kg} \text { at } 10 \text { weeks }\end{array}$ \\
\hline $\begin{array}{l}\text { Fava } \\
\text { et al. }\end{array}$ & $\begin{array}{l}\text { Fluoxetine, } \\
\text { sertraline and } \\
\text { paroxetine }\end{array}$ & $\begin{array}{l}\text { Double-blind, randomized trial which } \\
\text { assessed body weight changes during } \\
\text { treatment with SSRIs over } 26-32 \text { weeks }\end{array}$ & $\begin{array}{l}\text { Patients treated with paroxetine had significant weight gain, } \\
\text { while those treated with sertraline and fluoxetine had non- } \\
\text { significant weight gain and loss, respectively }\end{array}$ \\
\hline $\begin{array}{l}\text { Olguner } \\
\text { Eker } \\
\text { et al. }{ }^{[66]}\end{array}$ & $\begin{array}{l}\text { Sertraline, } \\
\text { escitalopram } \\
\text { and fluoxetine }\end{array}$ & $\begin{array}{l}\text { Case-control study on } 40 \text { patients and } 32 \\
\text { control aged } 29-49 \text { years with symptoms } \\
\text { of depression and anxiety, treated with } \\
\text { SSRIs during } 8 \text { weeks, assessing metabolic } \\
\text { variables }\end{array}$ & $\begin{array}{l}\text { As a group, SSRI use was related to higher body weight, } \\
\text { waist circumference and HDL-C, and lower insulin and } \\
\text { HOMA index levels. Escitalopram was also associated with } \\
\text { lower fasting glucose. Anthropometric changes were seen } \\
\text { after treatment only in patients with depression and not } \\
\text { anxiety. No anthropometric or biochemical changes were } \\
\text { found in subjects on sertraline, fluoxetine or venlafaxine }\end{array}$ \\
\hline $\begin{array}{l}\text { Pigott } \\
\text { et al. }{ }^{[114]}\end{array}$ & Escitalopram & $\begin{array}{l}\text { Double-blind, randomized, placebo- } \\
\text { controlled trial during } 8 \text { months, which } \\
\text { aimed to compare the safety and efficacy } \\
\text { of duloxetine and escitalopram in patients } \\
\text { with MDD }\end{array}$ & $\begin{array}{l}\text { Escitalopram was associated with increased systolic blood } \\
\text { pressure and body weight in comparison to duloxetine. No } \\
\text { significant changes were observed regarding diastolic blood } \\
\text { pressure }\end{array}$ \\
\hline $\begin{array}{l}\text { Beyazyüz } \\
\text { et }\left.a\right|^{[90]}\end{array}$ & $\begin{array}{l}\text { Paroxetine, } \\
\text { fluoxetine, } \\
\text { citalopram and } \\
\text { escitalopram }\end{array}$ & $\begin{array}{l}\text { Prospective cohort study including } 97 \\
\text { female patients with Generalized Anxiety } \\
\text { Disorder treated with SSRIs during } 16 \\
\text { weeks, evaluating various metabolic } \\
\text { variables }\end{array}$ & $\begin{array}{l}\text { After } 16 \text { weeks, subjects on paroxetine had significantly } \\
\text { higher LDL-C, TC and TAG, while those on citalopram or } \\
\text { escitalopram only had higher TAG. In contrast, subjects on } \\
\text { fluoxetine showed lower TC and TAG }\end{array}$ \\
\hline $\begin{array}{l}\text { Serodio } \\
\text { et al. }{ }^{[85]}\end{array}$ & All SSRIs & $\begin{array}{l}\text { Cross-sectional study on } 219 \text { participants } \\
\text { from the National Health and Nutrition } \\
\text { Examination Survey treated with SSRIs, } \\
\text { with the objective of evaluating their } \\
\text { influence on obesity and cardiovascular risk }\end{array}$ & $\begin{array}{l}\text { Independently of body mass index, subjects on SSRIs } \\
\text { showed lower systolic blood pressure and higher HDL-C in } \\
\text { comparison with subjects not on this medication }\end{array}$ \\
\hline $\begin{array}{l}\text { Wei } \\
\text { et al. }{ }^{[89]}\end{array}$ & $\begin{array}{l}\text { Paroxetine and } \\
\text { setraline }\end{array}$ & $\begin{array}{l}\text { Observational cohort study on } 2682 \text { adults } \\
\text { who received paroxetine or sertraline for at } \\
\text { least } 60 \text { continuous days and had LDL-C } \\
\text { measured twice, on and off the medication }\end{array}$ & $\begin{array}{l}\text { Mixed regression model analyses adjusting for age, gender, } \\
\text { comorbidities and hypolipemic medication, longer periods } \\
\text { of time on paroxetine or sertraline were associated with } \\
\text { increased LDL-C. Conversely, longer periods of time since } \\
\text { suspending paroxetine and sertraline were related to lo lower } \\
\text { LDL-C }\end{array}$ \\
\hline $\begin{array}{l}\text { Fjukstad } \\
\text { et al. }{ }^{[99]}\end{array}$ & $\begin{array}{l}\text { Paroxetine, } \\
\text { fluoxetine, } \\
\text { sertraline, } \\
\text { escitalopram } \\
\text { and citalopram }\end{array}$ & $\begin{array}{l}\text { Cross-sectional study on } 280 \text { patients with } \\
\text { schizophrenia or bipolar disorder treated } \\
\text { with SSRIs, evaluating their effect on } \\
\text { metabolic variables and prevalence of the } \\
\text { metabolic syndrome }\end{array}$ & $\begin{array}{l}\text { After adjusting for confounders, SSRI use was associated } \\
\text { with increased TC, LDL-C and TAG, and increased incidence } \\
\text { of metabolic syndrome. There were significant correlations } \\
\text { between SSRI doses and TC and LDL-C levels }\end{array}$ \\
\hline $\begin{array}{l}\text { Yosmaoğlu } \\
\text { et al. }{ }^{[83]}\end{array}$ & $\begin{array}{l}\text { Sertraline and } \\
\text { citalopram }\end{array}$ & $\begin{array}{l}\text { Experimental trial on } 14 \text { male subjects } \\
\text { treated with SSRI at least } 3 \text { months. Resting } \\
\text { metabolic rates, anthropometric measures } \\
\text { and serum lipids were assessed }\end{array}$ & $\begin{array}{l}\text { Resting metabolic rates decreased with increasing doses of } \\
\text { SSRIs, yet no relation was found between this variable and } \\
\text { body weight. Resting metabolic rates remained unchanged } \\
\text { with constant doses of SSRIs. Body weight was reduced } \\
\text { between the first and third weeks of treatment, but changes } \\
\text { were non-significant by the third month. TC levels were } \\
\text { significantly higher after } 3 \text { months of therapy }\end{array}$ \\
\hline
\end{tabular}

TAG: triacylglycerides; HDL-C: high-density lipoprotein cholesterol; LDL-C: low-density lipoprotein cholesterol; TC: total cholesterol; SSRI: selective serotonin reuptake inhibitor; MDD: major depressive disorder; OR: odds ratio

\section{Dysglycemia}

Although research on the effect of SSRIs on dysglycemia has been notoriously hindered by ample heterogeneity of study methodology, current evidence suggests each SSRI behaves distinctly regarding different outcome variables $^{[73,74]}$. In particular, fluvoxamine has shown the strongest association with the development of DM2, obtaining an odds ratio of 9.05 (95\% CI 1.08-75.58) in a recent large case-control study by Andersohn et al. ${ }^{[75]}$. On the other hand, sertraline has been reported to be associated with significant reductions in glycated 
hemoglobin levels in patients with $\mathrm{DM} 2$ and $\mathrm{MDD}$ at 10 weeks of treatment ${ }^{[76]}$, and escitalopram has been linked with significant reductions in fasting glucose levels ${ }^{[77]}$. Fluoxetine has been related to improved insulin sensitivity in patients with DM2, independently of weight loss ${ }^{[78]}$; while citalopram does not appear to impact measures of insulin sensitivity ${ }^{[79]}$ or be associated with $\mathrm{DM} 2^{[58]}$.

Evidence regarding paroxetine on this aspect is more controversial. Although this SSRI tends to be associated with increased risk of DM2 and obesity ${ }^{[75]}$, in short-term uses, it has proved to be innocuous, or even beneficial regarding glucose homeostasis: in a 5-week double-blind, randomized study by WeberHamann et al ${ }^{[80]}$ on non-diabetic patients with MDD, paroxetine was associated with improved insulin sensitivity. Paile-Hyvärinen et al. ${ }^{[81]}$ echoed these findings in a 10-week, single-blind study on 15 patients with MDD. The time-dependent effects of paroxetine on glucose metabolism highlight the importance of long-term prospective clinical studies in the characterization of the effects of SSRIs in cardiometabolic risk.

In summary, although SSRIs as a drug class are typically believed to increase the risk of $\mathrm{DM}^{[82]}$, current clinical evidence supports this notion predominantly for fluvoxamine and paroxetine ${ }^{[75]}$. This underlines the importance of pondering the metabolic profiles for each individual SSRI, especially in subjects with risk factors for DM2 or CVD.

\section{Dyslipidemia}

Similar to dysglycemia, SSRIs have been frequently linked to dyslipidemia. In the large Hordaland Health Study, subjects who used SSRIs were more prone to presenting components of the MS in comparison to subjects who did not use any psychotropic drugs, especially high triacylglycerides (TAG), high LDL-C, and low HDL-C ${ }^{[58]}$. Yosmaoğlu et al. ${ }^{[83]}$ obtained similar results in an Anatolian sample after 3 months of SSRI use, although comparable changes have been ascertained as early as after 5 weeks of treatment ${ }^{[84]}$. Nevertheless, some findings also suggest SSRIs to have no impact on or be beneficial for lipid profiles ${ }^{[85-87]}$.

These discrepancies may reflect the distinct characteristics of each specific SSRI. For example, in an 8-week case-control study on patients with symptoms of depression and anxiety, use of escitalopram was linked with a significant increase in HDL- $\mathrm{C}^{[6]}$. In contrast, in a 20 -week follow-up study, both paroxetine and sertraline were related to higher total cholesterol and LDL-C ${ }^{[88,89]}$. Similarly, after a 16-week follow-up, Beyazyuz et al.$^{[90]}$ found paroxetine to increase total cholesterol and TAG levels, while fluoxetine lowered both parameters. Lastly, most SSRIs - including fluoxetine, paroxetine, sertraline, and citalopram, as well as venlafaxine - have been associated with high TAG after 8-12 weeks of therapy ${ }^{[91-93]}$.

Thus, in general, SSRI use tends to be associated with high TAG in the earlier weeks, and then with hypercholesterolemia in the later months; while the effect on HDL-C appears not to be significant. This outlines SSRIs as important promoters of atherogenic dyslipidemia, and may worsen cardiometabolic risk in conjunction with other factors.

\section{Hypertension}

In contrast to the previously discussed risk factors, the impact of SSRIs on the development of hypertension may be more negligible ${ }^{[94-100]}$. Hypertension is notoriously not among the most frequent cardiovascular side effects of SSRIs, which include cardiac dysrhythmias, orthostatic hypotension, bradycardia, first-degree atrioventricular block, and syncope ${ }^{[94-96]}$. Among these, dysrhythmias are the most common (4\%), whether as a consequence of overdose or chronic use; in the case of the latter, the dysrhythmias tend to be welltolerated ${ }^{[97]}$. This profile renders SSRIs relatively safe regarding atherothrombotic risk ${ }^{[98]}$.

Various large-scale clinical epidemiological studies have reported that, as a drug class, SSRIs seem to be unrelated to significant increases in systolic or diastolic blood pressure, in patients with depression, anxiety 
disorders, bipolar disorder and schizophrenia ${ }^{[58,90,93,99]}$. At most, specific SSRIs such as sertraline and paroxetine may be linked to hypertension in $<1 \%$ of cases, while fluoxetine and citalopram appear to be innocuous in this regard ${ }^{[94]}$.

On the contrary, SSRIs may have a beneficial effect on blood pressure, especially by diminishing mean or systolic blood pressure, presumably via an inhibitory effect on the autonomic nervous system ${ }^{[100]}$. Notably, a report by Serodio et al.$^{[85]}$ found that, at any body mass index, systolic blood pressure was significantly lower in subjects treated with SSRIs than in those without antidepressant treatment, although this corresponded to a small $4 \mathrm{mmHg}$ difference. In summary, although scarce, currently available evidence suggests no relationship between SSRIs and hypertension, and this might not be one of the principal contributions of these drugs in the development of MS.

\section{CONCLUSIONS}

At present, enough evidence is available to affirm SSRIs intervene in the pathogenesis of certain components of MS. However, this impact is not equal for all SSRIs; rather, each drug in this groups has shown a particular cardiometabolic profile, differentially affecting body weight and composition, serum lipids, glycemia, blood pressure, and other parameters. These findings highlight the importance of holistic, patient-centered prescribing as a fundamental principle in clinical psychopharmacology. Further research is required to determine optimal approaches for the management of the metabolic effects of SSRIs. Future developments in psychopharmacology should consider the metabolic safety of novel drugs, in view of the burden CVD implies for public health, and the close association between mental and cardiometabolic disorders.

\section{DECLARATIONS}

\section{Authors' contributions}

Manuscript writing and editing, workgroup supervision, academic and methodological advisory: ChávezCastillo M, Velasco M, Bermúdez V, Rojas-Quintero J

Data gathering and manuscript writing: Ortega Á, Nava M, Fuenmayor J, Lameda V

\section{Financial support and sponsorship}

This work was supported by Research Grant no. CC-0437-10-21-09-10 from the Technological, Humanistic, and Scientific Development Council (CONDES), University of Zulia, and Research Grant no. FZ-0058-2007 from Fundacite Zulia.

\section{Conflicts of interest}

There are no conflicts of interest.

\section{Patient consent}

Not applicable.

\section{Ethics approval}

Not applicable.

\section{Copyright}

(c) The Author(s) 2018.

\section{REFERENCES}

1. Lépine JP, Briley M. The increasing burden of depression. Neuropsychiatr Dis Treat 2011;7:3-7.

2. Reddy MS. Depression: the disorder and the burden. Indian J Psychol Med 2010;32:1-2. 
3. Hare DL, Toukhsati SR, Johansson P, Jaarsma T. Depression and cardiovascular disease: a clinical review. Eur Heart J 2014;35:1365-72.

4. Colquhoun DM, Bunker SJ, Clarke DM, Glozier N, Hare DL, Hickie IB, Tatoulis J, Thompson DR, Tofler GH, Wilson A, Branagan MG. Screening, referral and treatment for depression in patients with coronary heart disease. Med J Aust 2013;198:483-4.

5. World Health Organization. Cardiovascular diseases. Media centre fact sheet. Updated May 2017. Available from: http://www.who.int/ mediacentre/factsheets/fs317/en/ [Last accessed on 10 Apr 2018]

6. Forman D, Bulwer BE. Cardiovascular disease: optimal approaches to risk factor modification of diet and lifestyle. Curr Treat Options Cardiovasc Med 2006;8:47-57.

7. Huang PL. A comprehensive definition for metabolic syndrome. Dis Model Mec 2009;2:231-7.

8. Olvera RL, Williamson DE, Fisher-Hoch SP, Vatcheva KP, McCormick JB. Depression, obesity, and metabolic syndrome: prevalence and risks of comorbidity in a population-based representative sample of Mexican Americans. J Clin Psychiatry 2015;76:e1300-5.

9. Kahl KG, Schweiger U, Correll C, Müller C, Busch ML, Bauer M, Schwarz P. Depression, anxiety disorders, and metabolic syndrome in a population at risk for type 2 diabetes mellitus. Brain Behav 2015;5:e00306.

10. McIntyre RS, Park KY, Law CW, Sultan F, Adams A, Lourenco MT, Lo AK, Soczynska JK, Woldeyohannes H, Alsuwaidan M, Yoon J, Kennedy SH. The association between conventional antidepressants and the metabolic syndrome: a review of the evidence and clinical implications. CNS Drugs 2010;24:741-53.

11. Chokka P, Tancer M, Yeragani VK. Metabolic syndrome: relevance to antidepressant treatment. J Psychiatry Neurosci 2006;31:414.

12. Mitchell AJ, Delaffon V, Vancampfort D, Correll CU, De Hert M. Guideline concordant monitoring of metabolic risk in people treated with antipsychotic medication: systematic review and meta-analysis of screening practices. Psychol Med 2012;42:125-47.

13. Riordan HJ, Antonini P, Murphy MF. Atypical antipsychotics and metabolic syndrome in patients with schizophrenia: risk factors, monitoring, and healthcare implications. Am Health Drug Benefits 2011;4:292-302.

14. Noordam R, Aarts N, Verhamme KM, Sturkenboom MC, Stricker BH, Visser LE. Prescription and indication trends of antidepressant drugs in the Netherlands between 1996 and 2012: a dynamic population-based study. Eur J Clin Pharmacol 2015;71:369-75.

15. Tripathi A, Avasthi A, Desousa A, Bhagabati D, Shah N, Kallivayalil RA, Grover S, Trivedi JK, Shinfuku N. Prescription pattern of antidepressants in five tertiary care psychiatric centres of India. Indian J Med Res 2016;143:507-13.

16. Santarsieri D, Schwartz TL. Antidepressant efficacy and side-effect burden: a quick guide for clinicians. Drugs Context 2015;4:212290.

17. Chittaranjan A, Chethan K, Sandarsh S. Cardiovascular mechanisms of SSRI drugs and their benefits and risks in ischemic heart disease and heart failure. Int Clin Psychopharmacol 2013;28:145-55.

18. Manabe I. Chronic inflammation links cardiovascular, metabolic and renal diseases. Circ J 2011;75:2739-48.

19. Berk M, Williams LJ, Jacka FN, O’Neil A, Pasco JA, Moylan S, Allen NB, Stuart AL, Hayley AC, Byrne ML, Maes M. So depression is an inflammatory disease, but where does the inflammation come from? BMC Med 2013;11:200.

20. Bica T, Castelló R, Toussaint LL, Montesó-Curto P. Depression as a risk factor of organic diseases: an international integrative review. $J$ Nurs Scholarsh 2017;49:389-99.

21. Chirinos DA, Murdock KW, LeRoy AS, Fagundes C. Depressive symptom profiles, cardio-metabolic risk and inflammation: results from the MIDUS study. Psychoneuroendocrinology 2017;82:17-25.

22. Mathews MJ, Mathews EH, Liebenberg L. The mechanisms by which antidepressants may reduce coronary heart disease risk. $B M C$ Cardiovasc Disord 2015;15:82.

23. Maes M, Berk M, Goehler L, Song C, Anderson G, Gałecki P, Leonard B. Depression and sickness behavior are Janus-faced responses to shared inflammatory pathways. BMC Med 2012;10:66.

24. Cattaneo A, Gennarelli M, Uher R, Breen G, Farmer A, Aitchison KJ, Craig IW, Anacker C, Zunsztain PA, McGuffin P, Pariante CM. Candidate genes expression profile associated with antidepressants response in the GENDEP study: differentiating between baseline 'predictors' and longitudinal 'targets'. Neuropsychopharmacology 2013;38:377-85.

25. Taler M, Gil-Ad I, Lomnitski L, Korov I, Baharav E, Bar M, Zolokov A, Weizman A. Immunomodulatory effect of selective serotonin reuptake inhibitors (SSRIs) on human T lymphocyte function and gene expression. Eur Neuropsychopharmacol 2007;17:774-80.

26. Serebruany VL, Gurbel PA, O’Connor CM. Platelet inhibition by sertraline and n-desmethylsertraline: a possible missing link between depression, coronary events, and mortality benefits of selective serotonin reuptake inhibitors. Pharmacol Res 2001;43:453-61.

27. Kubera M, Maes M, Kenis G, Kim Y, Lasoń W. Effects of serotonin and serotonergic agonists and antagonists on the production of tumor necrosis factor $\alpha$ and interleukin-6. Psychiatry Res 2005;134:251-8.

28. Young MR, Matthews JP. Serotonin regulation of T-cell subpopulations and of macrophage accessory function. Immunology $1995 ; 84: 148-52$.

29. Hellstrands K, Hermodsson S. Serotonergic 5-HT1a receptors regulate a cell contact-mediated interaction between natural killer cells and monocytes. Scand J Immunol 1993;37:7-18.

30. Nieuwland R, Berckmans RJ, McGregor S, Böing AN, Romijn FP, Westendorp RG, Hack CE, Sturk A. Cellular origin and procoagulant properties of microparticles in meningococcal sepsis. Blood 2000;95:930-5.

31. Shajib M, Khan W. The role of serotonin and its receptors in activation of immune responses and inflammation. Acta Physiol (Oxf) 2014;213:561-74.

32. Rudd ML, Nicolas AN, Brown BL, Fischer-Stenger K, Stewart JK. Peritoneal macrophages express the serotonin transporter. $J$ Neuroimmunol 2005;159:113-8.

33. de las Casas-Engel M, Domínguez-Soto A, Sierra-Filardi E, Bragado R, Nieto C, Puig-Kroger A, Samaniego R, Loza M, Corcuera MT, Gómez-Aguado F, Bustos M, Sánchez-Mateos P, Corbí AL. Serotonin skews human macrophage polarization through HTR2B and HTR7. J Immunol 2013;190:2301-10. 
34. Biswas SK, Mantovani A. Macrophage plasticity and interactionwith lymphocyte subsets: cancer as a paradigm. Nat Immunol 2010;11:889-96.

35. Ahern GP. 5-HT and the immune system. Curr Opin Pharmacol 2011;11:29-33.

36. Kopp S, Alstergren P. Blood serotonin and joint pain in seropositive versus seronegative rheumatoid arthritis. Mediators Inflamm 2002;11:211-7.

37. Gobin V, Van Steendam K, Denys D, Deforce D. Selective serotonin reuptake inhibitors as a novel class of immunosuppressants. Int Immunopharmacol 2014;20:148-56.

38. Tynan R, Weidenhofer J, Hinwood M, Cairns M, Day T, Walker F. A comparative examination of the anti-inflammatory effects of SSRI and SNRI antidepressants on LPS stimulated microglia. Brain Behav Immun 2012;26:469-79.

39. St-Onge J, Joanisse D, Simoneau J. The stimulation-induced increase in skeletal muscle glycogen synthase content is impaired in carriers of the glycogen synthase XbaI gene polymorphism. Diabetes 2001;50:195-8.

40. Levkovitz Y, Ben-shushan G, Hershkovitz A, Isaac R, Gil-Ad I, Shvartsman D, Ronen D, Weizman A, Zick Y. Antidepressants induce cellular insulin resistance by activation of IRS-1 kinases. Mol Cell Neurosci 2007;36:305-12.

41. Goldstein MR, Mascitelli L, Pezzetta F. Is the increase in LDL cholesterol induced by selective serotonin reuptake inhibitor therapy a blessing in disguise? Med Hypotheses 2010;74:955-6.

42. Avcikurt AS, Sinan S, Kockar F. Antidepressant and antipsychotic drugs differentially affect PON1 enzyme activity. $J$ Enzyme Inhib Med Chem 2015;30:245-9.

43. Al-Asmari AK, Ullah Z, Al Masoudi AS, Ahmad I. Simultaneous administration of fluoxetine and simvastatin ameliorates lipid profile, improves brain level of neurotransmitters, and increases bioavailability of simvastatin. J Exp Pharmacol 2017;9:47-57.

44. Roose SP, Laghrissi-Thode F, Kennedy JS, Nelson JC, Bigger JT Jr, Pollock BG, Gaffney A, Narayan M, Finkel MS, McCafferty J, Gergel I. Comparison of paroxetine and nortriptyline in depressed patients with ischemic heart disease. JAMA 1998;279:287-91.

45. Kemp AH, Quintana DS, Gray MA, Felmingham KL, Brown K, Gatt J. Impact of depression and antidepressant treatment on heart rate variability: a review and meta-analysis. Biol Psychiatry 2010;67:1067-74.

46. Licht CM, de Geus EJ, Seldenrijk A, van Hout HP, Zitman FG, van Dyck R, Penninx BW. Depression is associated with decreased blood pressure, but antidepressant use increases the risk for hypertension. Hypertension 2009;53:631-8.

47. Serebruany V, O'Connor C, Gurbel P. Effect of selective serotonin reuptake inhibitors on platelets in patients with coronary artery disease. Am J Cardiol 2001;87:1398-400.

48. Serebruany VL, Gurbel PA. The relations of major platelet receptor expression during myocardial infarction. Monitoring efficacy of GPIIb/IIIa inhibitors by measuring P-selectin? Thromb Haemost 1999;81:314-6.

49. Andrade C, Sandarsh S, Chethan K, Nagesh K. Serotonin reuptake inhibitor antidepressants and abnormal bleeding. J Clin Psychiatry 2010;71:1565-75.

50. Serebruany V. Selective serotonin reuptake inhibitors and increased bleeding risk: are we missing something? Am J Med 2006;119:113-6.

51. Musselman D, Marzec U, Manatunga A, Penna S, Reemsnyder A, Knight BT, Baron A, Hanson SR, Nemeroff CB. Platelet reactivity in depressed patients treated with paroxetine. Arch Gen Psychiatry 2000;57:875-82.

52. Tseng Y, Chiang M, Huang T, Su K, Lane H, Lai Y. A selective serotonin reuptake inhibitor, citalopram, inhibits collagen-induced platelet aggregation and activation. Thromb Res 2010;126:517-23.

53. Lekakis J, Ikonomidis I, Papoutsi Z, Moutsatsou P, Nikolaou M, Parissis J, Kremastinos DT. Selective serotonin re-uptake inhibitors decrease the cytokine-induced endothelial adhesion molecule expression, the endothelial adhesiveness to monocytes and the circulating levels of vascular adhesion molecules. Int J Cardiol 2010;139:150-8.

54. Herr N, Mauler M, Witsch T, Stallmann D, Schmitt S, Mezger J, Bode C, Duerschmied D. Acute fluoxetine treatment induces slow rolling of leukocytes on endothelium in mice. PLoS One 2014;9:e88316.

55. Hiles S, Révész D, Lamers F, Giltay E, Penninx B. Bidirectional prospective associations of metabolic syndrome components with depression, anxiety, and antidepressant use. Depress Anxiety 2016;33:754-64.

56. Shrivastava A, Johnston M. Weight-gain in psychiatric treatment: risks, implications, and strategies for prevention and management. Mens Sana Monogr 2010;8:53-68.

57. Ferguson JM. SSRI antidepressant medications: adverse effects and tolerability. Prim Care Companion J Clin Psychiatry 2001;3:22-7.

58. Raeder M, Bjelland I, Vollset S, Steen V. Obesity, dyslipidemia, and diabetes with selective serotonin reuptake inhibitors. $J$ Clin Psychiatry 2006;67:1974-82.

59. Serretti A, Mandelli L. Antidepressants and body weight. J Clin Psychiatry 2010;71:1259-72

60. McIntyre RS, Park KY, Law CW, Sultan F, Adams A, Lourenco MT, Lo AK, Soczynska JK, Woldeyohannes H, Alsuwaidan M, Yoon J, Kennedy SH. The association between conventional antidepressants and the metabolic syndrome: a review of the evidence and clinical implications. CNS Drugs 2010;24:741-53.

61. Reekie J, Hosking S, Prakash C, Kao K, Juonala M, Sabin M. The effect of antidepressants and antipsychotics on weight gain in children and adolescents. Obes Rev 2015;16:566-80.

62. Wagner KD, Ambrosini P, Rynn M, Wohlberg C, Yang R, Greenbaum MS, Childress A, Donnelly C, Deas D; Sertraline Pediatric Depression Study Group. Efficacy of sertraline in the treatment of children and adolescents with major depressive disorder: two randomized controlled trials. JAMA 2003;290:1033-41.

63. Croft H, Settle E Jr, Houser T, Batey SR, Donahue RM, Ascher JA. A placebo-controlled comparison of the antidepressant efficacy and effects on sexual functioning of sustained-release bupropion and sertraline. Clin Ther 1999;21:643-58.

64. de Jonghe F, Ravelli DP, Tuynman-Qua H. A randomized, double-blind study of fluoxetine and maprotiline in the treatment of major 
depression. Pharmacopsychiatry 1991;24:62-7.

65. Michelson D, Amsterdam JD, Quitkin FM, Reimherr FW, Rosenbaum JF, Zajecka J, Sundell KL, Kim Y, Beasley CM Jr. Changes in weight due to a 1-year trial of fluoxetine. Am J Psychiatry 1999;156:1170-6.

66. Olguner Eker Ö, Özsoy S, Eker B, Doğan H. Metabolic effects of antidepressant treatment. Noro Psikiyatr Ars 2017;54:49-56.

67. Fava M, Judge R, Hoog SL, Nilsson ME, Koke SC. Fluoxetine versus sertraline and paroxetine in major depressive disorder: changes in weight with long-term treatment. J Clin Psychiatry 2000;61:863-7.

68. Mansoor B, Rengasamy M, Hilton R, Porta G, He J, Spirito A, Emslie GJ, Mayes TL, Clarke G, Wagner KD, Shamseddeen W, Birmaher B, Ryan N, Brent D. The bidirectional relationship between body mass index and treatment outcome in adolescents with treatment-resistant depression. J Child Adolesc Psychopharmacol 2013;23:458-67.

69. Emslie GJ, Heiligenstein JH, Hoog SL, Wagner KD, Findling RL, McCracken JT, Nilsson ME, Jacobson JG. Fluoxetine treatment for prevention of relapse of depression in children and adolescents: a double-blind, placebo-controlled study. J Am Acad Child Adolesc Psychiatry 2004;43:1397-405.

70. Nilsson M, Joliat M, Miner C, Brown E, Heiligenstein J. Safety of subchronic treatment with fluoxetine for major depressive disorder in children and adolescents. J Child Adolesc Psychopharmacol 2004;14:412-7.

71. Calarge CA, Mills JA, Janz KF, Burns TL, Coryell WH, Zemel BS. Body composition in adolescents during treatment with selective serotonin reuptake inhibitors. Pediatrics 2017;140:e20163943.

72. Gibson-Smith D, Bot M, Milaneschi Y, Twisk J, Visser M, Brouwer IA, Penninx BW. Major depressive disorder, antidepressant use, and subsequent 2-year weight change patterns in the Netherlands study of depression and anxiety. J Clin Psychiatry 2015;77:e144-51.

73. McIntyre R, Soczynska J, Konarski J, Kennedy S. The effect of antidepressants on glucose homeostasis and insulin sensitivity: synthesis and mechanisms. Expert Opin Drug Saf 2005;5:157-68.

74. Derijks H, Meyboom R, Heerdink E, De Koning F, Janknegt R, Lindquist M, Egberts AC. The association between antidepressant use and disturbances in glucose homeostasis: evidence from spontaneous reports. Eur J Clin Pharmacol 2008;64:531-8.

75. Andersohn F, Schade R, Suissa S, Garbe E. Long-term use of antidepressants for depressive disorders and the risk of diabetes mellitus. Am J Psychiatry 2009;166:591-8.

76. Goodnick PJ, Kumar A, Henry JH, Buki VM, Goldberg RB. Sertraline in coexisting major depression and diabetes mellitus. Psychopharmacol Bull 1997;33:261-4.

77. Dhavale HS, Panikkar V, Jadhav BS, Ghulghule M, Agari AD. Depression and diabetes: impact of antidepressant medications on glycaemic control. J Assoc Physicians India 2013;61:896-9.

78. Maheux P, Ducros F, Bourque J, Garon J, Chiasson JL. Fluoxetine improves insulin sensitivity in obese patients with non-insulindependent diabetes mellitus independently of weight loss. Int J Obes Relat Metab Disord 1997;21:97-102.

79. Kauffman RP, Castracane VD, White DL, Baldock SD, Owens R. Impact of the selective serotonin reuptake inhibitor citalopram on insulin sensitivity, leptin and basal cortisol secretion in depressed and non-depressed euglycemic women of reproductive age. Gynecol Endocrinol 2005;21:129-37.

80. Weber-Hamann B, Gilles M, Lederbogen F, Heuser I, Deuschle M. Improved insulin sensitivity in 80 nondiabetic patients with MDD after clinical remission in a double-blind, randomized trial of amitriptyline and paroxetine. J Clin Psychiatry 2006;67:1856-61.

81. Paile-Hyvärinen M, Wahlbeck K, Eriksson JG. Quality of life and metabolic status in mildly depressed women with type 2 diabetes treated with paroxetine: a single-blind randomised placebo controlled trial. BMC Fam Pract 2003;4:7.

82. Yoon JM, Cho EG, Lee HK, Park SM. Antidepressant use and diabetes mellitus risk: a meta-analysis. Korean J Fam Med 2013;34:228-40.

83. Yosmaoğlu A, Fıstıkcı N, Keyvan A, Hacıoğlu M, Erten E, Saatçioğlu Ö, Kora K. Correlation of selective serotonin re-uptake inhibitor use with weight gain and metabolic parameters. Anadolu Psikiyatri Derg 2013;14:245-51.

84. Gabriel A. Changes in plasma cholesterol in mood disorder patients: does treatment make a difference? J Affect Disord 2007;99:273-8.

85. Serodio KJ, Ardern CI, Rotondi M, Kuk J. Tricyclic and SSRI usage influences the association between BMI and health risk factors. Clin Obes 2014;4:296-302.

86. Deisenhammer EA, Kramer-Reinstadler K, Liensberger D, Kemmler G, Hinterhuber H, Fleischhacker WW. No evidence for an association between serum cholesterol and the course of depression and suicidality. Psychiatry Res 2004;121:253-61.

87. Ma Y, Balasubramanian R, Pagoto SL, Schneider KL, Hebert JR, Phillips LS, Goveas JS, Culver AL, Olendzki BC, Beck J, Smoller JW, Sepavich DM, Ockene JK, Uebelacker L, Zorn M, Liu S. Relations of depressive symptoms and antidepressant use to body mass index and selected biomarkers for diabetes and cardiovascular disease. Am J Public Health 2013;103:e34-43.

88. Herran A, Ramirez ML, Carrera M, Garcia-Unzueta MT, Sierra-Biddle D, Rodríguez-Cabo B, Ayestarán A, Hoyuela F, VázquezBarquero JL. Panic disorder, treatment with selective serotonin reuptake inhibitors, and cholesterol levels. J Clin Psychopharmacol 2006;26:538-40.

89. Wei F, Crain AL, Whitebird RR, Godlevsky OV, O'Connor PJ. Effects of paroxetine and sertraline on low-density lipoprotein cholesterol: an observational cohort study. CNS Drugs 2009;23:857-65.

90. Beyazyüz M, Albayrak Y, Eğilmez OB, Albayrak N, Beyazyüz E. Relationship between SSRIs and metabolic syndrome abnormalities in patients with generalized anxiety disorder: a prospective study. Psychiatry Investig 2013;10:148-54.

91. Teitelbaum M. Severe hypertriglyceridemia secondary to venlafaxine and fluoxetine. Psychosomatics 2001;42:440-1.

92. Teitelbaum M. Severe and moderate hypertriglyceridemia secondary to citalopram and fluoxetine. Psychosomatics 2000;41:448-9.

93. Kesim M, Tiryaki A, Kadioglu M, Muci E, Kalyoncu NI, Yaris E. The effects of sertraline on blood lipids, glucose, insulin and HBA1C levels: a prospective clinical trial on depressive patients. J Res Med Sci 2011;16:1525-31.

94. Khawaja I, Feinstein R. Cardiovascular effects of selective serotonin reuptake inhibitors and other novel antidepressants. Heart Dis 

2003;5:153-60.

95. Pacher P, Ungvari Z, Nanasi PP, Furst S, Kecskemeti V. Speculations on difference between tricyclic and selective serotonin reuptake inhibitor antidepressants on their cardiac effects. Is there any? Curr Med Chem 1999;6:469-80.

96. Nezafati MH, Eshraghi A, Vojdanparast M, Abtahi S, Nezafati P. Selective serotonin reuptake inhibitors and cardiovascular events: a systematic review. J Res Med Sci 2016;21:66.

97. Kostev K, Rex J, Eith T, Heilmaier C. Which adverse effects influence the dropout rate in selective serotonin reuptake inhibitor (SSRI) treatment? Results for 50,824 patients. Ger Med Sci 2014;12:Doc15.

98. Katsi VK, Marketou M, Vamvakou G, Makris T, Tousoulis D, Stefanadis CI, Vardas P, Kallikazaros IE. Novel antidepressant drugs, arterial hypertension and cardiovascular disease. Recent Pat Cardiovasc Drug Discov 2013;8:178-85.

99. Fjukstad KK, Engum A, Lydersen S, Dieset I, Steen NE, Andreassen OA, Spigset O. Metabolic abnormalities related to treatment with selective serotonin reuptake inhibitors in patients with schizophrenia or bipolar disorder. J Clin Psychopharmacol 2016;36:615-20.

100. Licht C, Penninx B, Geus E. Effects of antidepressants, but not psychopathology, on cardiac sympathetic control: a longitudinal study. Neuropsychopharmacology 2012;37:2487-95.

101. Hinze-Selch D, Schuld A, Kraus T, Kühn M, Uhr M, Haack M, Pollmächer T. Effects of antidepressants on weight and on the plasma levels of leptin, TNF-alpha and soluble TNF receptors: a longitudinal study in patients treated with amitriptyline or paroxetine. Neuropsychopharmacology 2000;23:13-9.

102. Weber E, Stack J, Pollock BG, Mulsant B, Begley A, Mazumdar S, Reynolds CF3rd. Weight change in older depressed patients during acute pharmacotherapy with paroxetine and nortriptyline: a double-blind randomized trial. Am J Geriatr Psychiatry 2000;8:245-50.

103. Nemeroff CB, Evans DL, Gyulai L, Sachs GS, Bowden CL, Gergel IP, Oakes R, Pitts CD. Double-blind, placebo-controlled comparison of imipramine and paroxetine in the treatment of bipolar depression. Am J Psychiatry 2001;158:906-12.

104. Paile-Hyvärinen M, Wahlbeck K, Eriksson JG. Quality of life and metabolic status in mildly depressed patients with type 2 diabetes treated with paroxetine: a double-blind randomised placebo controlled 6-month trial. BMC Fam Pract 2007;8:34.

105. Ye Z, Chen L, Yang Z, Li Q, Huang Y, He M, Zhang S, Zhang Z, Wang X, Zhao W, Hu J, Liu C, Qu S, Hu R. Metabolic effects of fluoxetine in adults with type 2 diabetes mellitus: a meta-analysis of randomized placebo-controlled trials. PLoS One 2011;6:e21551.

106. O’Kane M, Wiles PG, Wales JK. Fluoxetine in the treatment of obese type 2 diabetic patients. Diabet Med 1994;11:105-10.

107. Breum L, Bjerre U, Bak JF, Jacobsen S, Astrup A. Long-term effects of fluoxetine on glycemic control in obese patients with noninsulin-dependent diabetes mellitus or glucose intolerance: influence on muscle glycogen synthase and insulin receptor kinase activity. Metabolism 1995;44:1570-6.

108. Fava M. Weight gain and antidepressants. J Clin Psychiatry 2000;61:37-41.

109. Moon CA, Jesinger DK. The effects of psychomotor performance of fluvoxamine versus mianserin in depressed patients in general practice. Br J Clin Pract 1991;45:259-62.

110. Nihalani N, Schwartz TL, Siddiqui UA, Megna JL. Weight gain, obesity, and psychotropic prescribing. J Obes 2011;2011:893629.

111. Aberg-Wistedt A, Agren H, Ekselius L, Bengtsson F, Akerblad AC. Sertraline versus paroxetine in major depression: clinical outcome after six months of continuous therapy. J Clin Psychopharmacol 2000;20:645-52.

112. Bouwer CD, Harvey BH. Phasic craving for carbohydrate observed with citalopram. Int Clin Psychopharmacol 1996;11:273-8.

113. Emslie GJ, Ventura D, Korotzer A, Tourkodimitris S. Escitalopram in the treatment of adolescent depression: a randomized placebocontrolled multisite trial. J Am Acad Child Adolesc Psychiatry 2009;48:721-9.

114. Pigott TA, Prakash A, Arnold LM, Aaronson ST, Mallinckrodt CH, Wohlreich MM. Duloxetine versus escitalopram and placebo: an 8-month, double-blind trial in patients with major depressive disorder. Curr Med Res Opin 2007;23:1303-18. 